\title{
Inhibition of Adherence of Neisseria gonorrhoeae by
}

\section{Human Genital Secretions}

\author{
EDMUND C. TRAMONT \\ From the Department of Bacterial Diseases, Division of Communicable Disease and Immunology, \\ Walter Reed Army Institute of Research, and The Infectious Disease Service, \\ Walter Reed Army Medical Center, Washington, D. C. 20012
}

A B S T RAC T Local genital antibodies to the infecting strains of Neisseria gonorrhoeae were demonstrated by indirect immunofluorescence (binding antibody) and by their ability to inhibit the attachment of gonococci to epithelial cells (functional antibody). Both IgG and IgA classes of immunoglobulin were involved, and the IgA component were primarily of a secreting (11S) nature. The ability of local genital antibody to inhibit attachment appears to persist for at least a short period of time and to be relatively strain specific.

\section{INTRODUCTION}

Infections caused by Neisseria gonorrhoeae involve primarily the mucosal surfaces of the cervic, urethra, rectum, and oropharynx and they have been shown to evoke a local antibody response $(1,2)$. However, the function of these antibodies has remained unclear. Because the initial step in colonization of most pathogens is adherence to the host cell, the ability of these antibodies to inhibit such an occurrence was studied.

This report verifies the stimulation of local antibodies by $N$. gonorrhoeae, documents the ability of those antibodies to inhibit attachment to epithelial cells for at least $3 \mathrm{wk}-4 \mathrm{mo}$, and demonstrates the antibody class that mediates this function.

\section{METHODS}

Gonococcal strains. Strains of $N$. gonorrhoeae freshly isolated from patients at the Walter Reed Army Medical Center and strain 9 (kindly supplied by Dr. Douglas Kellogg, Center for Disease Control, Atlanta, Ga.) were used. Bacterial morphology and carbohydrate fermentation reactions were verified periodically. Colonial types (3) were carefully maintained by serial selection. Representative organisms of colonial types 1 and 2 of four strains were shown by electron microscopy to be piliated (4).

Received for publication 8 June 1976 and in revised form 18 August 1976.
Local secretions. Genital secretions were obtained by instilling $10-15 \mathrm{ml}$ of normal saline with $0.1 \% \mathrm{NaN}_{3}$ into the vagina, taking care to wash the cervix, and then aspirating the specimen. Unless otherwise stated, the specimens were then examined for red blood cells and sperm under light microscopy and discarded if any were present. Male secretions were obtained by collecting from $0.1-0.3 \mathrm{ml}$ of purulent secretion with a tuberculin syringe and suspending it in normal saline. The secretions were sonicated (Branson Instruments, Inc., Stamford, Conn.) for $30 \mathrm{~s}$ to break up mucous plugs and then clarified by centrifugation at $141 \mathrm{~g}$ for $10 \mathrm{~min}$. The supernate was concentrated by filtration (Amicon PM10 filter, Amicon Corp., Scientific Systems Div., Lexington, Mass.) and stored at $-20^{\circ} \mathrm{C}$.

Epithelial cell adhesion. Epithelial cell adhesion was modified from the methods of Punsalang and Sawyer (5) and Swanson (6). Gonococci of colony type T1 or T2 were scraped from an 18-20-h culture grown on GC medium (Difco Laboratories, Detroit, Mich.) plus defined supplement (3), suspended in medium 199 (Microbiological Associates, Bethesda, Md.), supplemented with $2 \%$ bovine serum albumin, and vortexed to break up large clumps of organisms.

Human buccal epithelial cells, vaginal cells, or cervical cells were scraped with a wooden applicator, suspended in

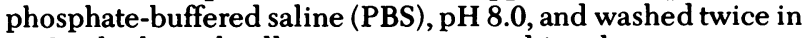
PBS. The buccal cells were enumerated in a hemocytometer and adjusted in medium 199 to a concentration of $2 \times 10^{5}$ cells/ml. Equal volumes $(25 \mu \mathrm{l})$ of buccal cells and gonococci $(25 \mu \mathrm{l})$ were adjusted in medium 199 to a 50:1 ratio of organisms to epithelial cells and incubated at $37^{\circ} \mathrm{C}$ for $30 \mathrm{~min}$ on a shaker apparatus. A slight increase $(5-15 \%)$ in the number of organisms often occurred in that time interval. Pooled hyperimmune rabbit antisera conjugated with horseradish peroxidase ( 7 ) were then used to identify the gonococci by incubating $0.1 \mathrm{ml}$ of the tagged pooled antiserum for $30 \mathrm{~min}$ on a shaker apparatus. The cells were washed in normal saline, centrifuged, resuspended in $0.1 \mathrm{ml}$ of normal saline, fixed with $95 \%$ ethyl alcohol for $10 \mathrm{~min}$, dried onto slides, and overlaid with $3^{\prime}, 3^{\prime}$-diaminobenzidine tetrachloride (Sigma Chemical Co., St. Louis, Mo.) in 0.1 M Tris in $50 \%$ ethanol, $\mathrm{pH}$ 7.4. The slides were examined under oil immersion and the number of buccal cells with organisms attached was recorded.

Inhibition of epithelial cell adhesion (IEA). ${ }^{1}$ IEA was

\footnotetext{
${ }^{1}$ Abbreviations used in this paper: IEA, inhibition of epithelial cell adhesion; IFA, indirect immunofluorescent antibody; PBS, phosphate-buffered saline.
} 
TABLE I

Antibody Concentrations and Indirect Immunofluorescent Antibody (IFA) Titers in Vaginal Secretions

\begin{tabular}{|c|c|c|c|c|c|c|c|c|}
\hline \multirow[b]{2}{*}{ Patient } & \multirow[b]{2}{*}{ Date } & \multicolumn{2}{|c|}{$\begin{array}{l}\text { Immuno- } \\
\text { fluorescent } \\
\text { titers* }\end{array}$} & \multicolumn{2}{|c|}{ Immunoglobin } & \multicolumn{2}{|c|}{ Specific ab titers $\downarrow$} & \multirow[b]{2}{*}{$\operatorname{IgG} / \operatorname{IgA}$} \\
\hline & & $\operatorname{lgG}$ & $\operatorname{IgA}$ & $\operatorname{IgG}$ & $\operatorname{Ig} A$ & $\operatorname{IgG}$ & IgA & \\
\hline & \multicolumn{8}{|c|}{$m g / 100 m l$} \\
\hline \multirow[t]{4}{*}{135} & 9 Jun & $<2$ & $<2$ & 2.2 & 0.4 & (0) & $(0)$ & $5.4: 1$ \\
\hline & 17 Jun & $<2$ & $<2$ & 2.2 & 0.4 & (0) & (0) & 5.4 \\
\hline & 23 Jun & $<2$ & $<2$ & 2.2 & 0.5 & (0) & (0) & 4.3 \\
\hline & $7 \mathrm{Jul}$ & $<2$ & $<2$ & 1.8 & 0.4 & (0) & (0) & 4.5 \\
\hline \multirow[t]{3}{*}{152} & $7 \mathrm{Jul}$ & 32 & $<2$ & 40.0 & 4.0 & 0.80 & $(0)$ & 10.0:1 \\
\hline & $25 \mathrm{Jul}$ & 128 & $<2$ & 42.0 & 3.9 & 3.05 & (0) & 10.8 \\
\hline & 8 Aug & 16 & $<2$ & 38.0 & 3.2 & 0.42 & (0) & 11.9 \\
\hline \multirow[t]{3}{*}{136} & 17 Jun & 8 & 4 & 9.8 & 0.8 & 0.82 & 5.00 & 12.3: 1 \\
\hline & 22 Jun & 32 & 16 & 13.5 & 23.0 & 2.37 & 0.70 & 0.6 \\
\hline & 30 Jun & 128 & $<2$ & 3.5 & 5.9 & 36.57 & $(0)$ & 0.6 \\
\hline \multirow[t]{3}{*}{148} & $14 \mathrm{Jul}$ & 8 & 64 & 8.7 & 4.2 & 0.92 & 15.24 & 2.1:1 \\
\hline & $28 \mathrm{Jul}$ & 8 & 8 & 8.5 & 3.9 & 0.94 & 2.05 & 2.2 \\
\hline & 4 Aug & 16 & 8 & 17.3 & 7.8 & 0.92 & 1.03 & 2.2 \\
\hline \multirow[t]{4}{*}{174} & $11 \mathrm{Jul}$ & 64 & 64 & 8.4 & 1.4 & 7.62 & 45.71 & $6.0: 1$ \\
\hline & $18 \mathrm{Jul}$ & 128 & 64 & 18.3 & 5.5 & 6.99 & 11.64 & 3.3 \\
\hline & $11 \mathrm{Sep}$ & 64 & 16 & 9.2 & 2.7 & 6.96 & 5.93 & 3.4 \\
\hline & 19 Sep & 32 & 8 & 4.3 & 1.4 & 7.44 & 5.61 & 3.1 \\
\hline \multirow[t]{4}{*}{134} & 9 Jun & 4 & 2 & 33.0 & 2.2 & 0.12 & 0.91 & 15.0:1 \\
\hline & 17 Jun & 16 & 4 & 8.7 & 1.7 & 1.84 & 2.35 & 5.1 \\
\hline & 23 Jun & 32 & 4 & 17.0 & 2.6 & 1.88 & 1.54 & 6.5 \\
\hline & 30 Jun & 64 & 16 & 33.0 & 13.1 & 1.94 & 1.22 & 2.5 \\
\hline \multirow[t]{3}{*}{143} & $7 \mathrm{Jul}$ & 128 & 16 & 21.1 & 13.3 & 6.07 & 1.20 & $1.6: 1$ \\
\hline & $14 \mathrm{Jul}$ & 64 & 32 & 17.0 & 7.4 & 3.76 & 4.32 & 2.3 \\
\hline & $21 \mathrm{Jul}$ & 64 & 8 & 28.2 & 12.4 & 2.27 & 0.65 & 2.3 \\
\hline N1 & Control & $<2$ & $<2$ & 4.2 & 2.3 & $(0)$ & $(0)$ & 1.8 \\
\hline N2 & Control & $<2$ & $<2$ & 3.6 & 1.9 & (0) & (0) & 1.9 \\
\hline N3 & Control & $<2$ & $<2$ & 2.8 & 1.6 & (0) & (0) & 1.8 \\
\hline N4 & Control & 8 & $<2$ & 7.4 & 3.0 & 1.08 & (0) & 2.5 \\
\hline
\end{tabular}

* Patients vs. homologous strain; control vs. GC9, reciprocal titer.

$\$$ IFA titer $\div$ immunoglobin concentration.

tested by mixing an equal volume of serially diluted local secretion $(0.05 \mathrm{ml})$ to the reactive mixture of epithelial cells and gonococci $(0.05 \mathrm{ml})$. $A \geq 50 \%$ reduction of the number of buccal cells with organisms attached as compared to controls without secretions was considered significant. Other controls included the substitution for the secretion of pooled hyperimmune rabbit antisera made to piliated organisms and epithelial cells without gonococci. In some experiments secretions absorbed with the test strains were also included as a control. Because various gonococcal strains attached to epithelial cells at different percentage rates, the following formula was used to determine the minimum number of epithelial cells to count to assure that a $50 \%$ reduction was significant at $95 \%$ confidence limits: $n=(2 \times 1.96 / d)^{2}=15.37 / d^{2}$ where 1.96 corresponds to an error rate of $5 \%$ (using the standard normal distribution) and $d=\left(2 \operatorname{arc} \sin \sqrt{P_{c}}-2 \operatorname{arc} \sin \sqrt{P_{a b}}\right)$ where $P_{c}$ denotes the "true" fraction of cells in the control with at least one organism attached. $P_{a b}$ denotes the corresponding value in the group receiving antibody with $a \geq 50 \%$ reduction; therefore, $P_{a b}=0.5 \times P_{c}$.

The minimum acceptable number of control epithelial cells with organisms attached was $30 \%$. The end pont was usually quite distinct. A 50:1 organism-to-epithelial cell ratio was used to optimize the detection of antibody effect.

Immunofluorescence. Indirect immunofluorescent antibody (IFA) was determined by standard techniques (8). The antigens were gonococcal organisms grown from $18-20 \mathrm{~h}$ on GC agar plus defined supplement, suspended in PBS ( $\mathrm{pH} 7.7$ ), washed once, and dried onto slides. Fluorescein-conjugated antisera to human globulins IgG or IgA (heavy chain-specific) (Behring Diagnostics, American Hoechst Corp., Sommer-

\section{8 \\ E. C. Tramont}


ville, N. J., or Hyland Div., Travenal Laboratories, Inc., Costa Mesa, Calif.) or human colostrum absorbed with normal serum (Behring Diagnostics) was used. The human colostrum was conjugated with fluorescein isothiocyanate in our laboratory by to the modified method of Cherry and chromatographed on Sephadex G25 as described by Goldman (9). The fluorescein to protein molar ratios ranged from 2 to 4 and the specific antibody concentration was between 2 and $3 \mathrm{mg} / \mathrm{ml}$.

The slides were incubated at room temperature with human secretions for $20 \mathrm{~min}$, washed in two changes of PBS (10 min each), reincubated with fluorescein-conjugated antisera, rewashed, and mounted in buffered glycerin. Specimens were examined with a Zeiss Universal microscope equipped with a $100 \times$ achromatic immersion objective with iris diaphragm, $8 \times$ eyepiece and 1.25-Optvar magnifying equipment (Carl Zeiss, Inc., New York). The ultraviolet light source was a $200 \mathrm{~W}$ mercury vapor arc lamp. A BG 12 excitation filter and a combination of barrier filters, \#53 and \#44, were used.

Reactions were recorded as follows: $4+$, brilliant fluorescence of all organisms in field $3+$, well-defined fluorescence of all organisms in field; $2+$, low-intensity but definite fluorescence of $75 \%$ or more of the organisms in the field; $1+$, occasional organisms with low-intensity fluorescence. A positive reaction was considered $2+$ reactivity or greater.

Quantitation of immunoglobulin. Immunoglobulins were quantitated by radial diffusion immunoprecipitation (Mancini method) (10) with commercial low-level plates (Behring Diagnostics). Results were expressed as concentration in milligrams per $100 \mathrm{ml}$. The reproducibility of the measurements was between 10 and $15 \%$. The quantitative measurements could detect as little as $0.5 \mathrm{mg} / \mathrm{ml}$ of the immunoglobulin measured.

Standardization of titers. Specific immunofluorescent titers were standardized on the basis of the concentration in milligrams per $100 \mathrm{ml}$ of secretion by dividing the IFA titer by the quantity of specific immunoglobulin (IgG or IgA). In some experiments the vaginal secretions were adjusted to contain $50 \%$ of the $11 \mathrm{~S}$ IgA standard purified from human parotid saliva (kindly supplied by Jane Suderstrom, Walter Reed Army Institute of Research). This standard equalled $0.19 \mu \mathrm{g} / \mathrm{ml}$ of $11 \mathrm{~S} \mathrm{IgA}$ as determined by computation with an extinction coefficient $\left(\mathrm{E}_{280 \mathrm{~nm}}{ }^{0.1} \%\right)$ of 13.9 (11).

Separation of immunoglobulin. Linear sucrose density gradients (12) were used to separate immunoglobulins in vaginal secretions. Markers included 7S human IgG labeled with ${ }^{125}$ I (kindly supplied by Wendell Zollinger, Walter Reed Army Institute of Research) and 11S crystalline beet catalase (Worthington Biochemical Corp., Freehold, N. J.) (13). Appropriate fractions were pooled and the dialyzed against $66.7 \mathrm{mM}$ PBS to remove the sucrose, and fianlly against $33.3 \mathrm{mM}$ PBS before lyophilization. Pools were rehydrated to contain no less than $0.10 \mathrm{mg} / \mathrm{ml}$ of $11 \mathrm{~S}$ IgA.

Absorption of secretions. Secretions were absorbed by mixing a heavy suspension of washed organisms, scraped from a 16-18-h-old culture, and incubating the mixture for $1 \mathrm{~h}$ at $37^{\circ} \mathrm{C}$ and then $1 \mathrm{~h}$ at $4^{\circ} \mathrm{C}$. The organisms were removed by centrifugation. The procedure was performed thrice.

\section{RESULTS}

Local antibody response in vaginal secretions. Specific IgA and IgG antibody directed against the homologous (infecting) organism was measured in vaginal secretions by IFA (Table 1). Because the method of collecting the local secretion resulted in
TABLE II

Immunofluorescent IgA Antibody Titers with 7S and 11S Conjugates

\begin{tabular}{ccrc}
\hline & & & IgA conjugate \\
\cline { 3 - 4 } Patient & Date & 75 & 115 \\
\hline \multirow{2}{*}{134} & 9 June & $2 *$ & 2 \\
& 17 June & 4 & 2 \\
& 23 June & 4 & 4 \\
& 30 June & 16 & 16 \\
136 & 17 June & 4 & 4 \\
& 22 June & 16 & 8 \\
& 30 June & 2 & $<2$ \\
\hline
\end{tabular}

$*$ Reciprocal titers.

variations in the concentrations of immunoglobins, the titers were standardized on the basis of concentration of specific antibody (see Methods). All of the patients were treated when the initial sample was obtained and were cultured negative when follow-up specimens were obtained. Patients 135 and 152 had acute symptomatic gonococcal pelvic inflammatory disease, patients 136,148 , and 174 were asymptomatic gonococcal carriers who probably infected their male partners (i.e. they were named as consorts); and patients 134 and 143 were named as recent contacts (i.e. who infected whom could not be determined).

Specific IgG could be measured throughout the time interval studied in six of seven cases (Table I). Three patients $(152,136$, and 134) demonstrated titer increases: two that peaked $(136,152)$ and one that plateaued (134). Patients 148 and 174 had levels that remained relatively constant and patient 143 showed a steady decline.

In contrast, the specific IgA antibody level decreased from its peak level in five instances and could not be measured at all in two patients (135 and 152). The two patients (134 and 143) who demonstrated increases in their specific IgA antibody titers were named as recent contacts of infected men and it could not be determined whether they were recently infected or asymptomatic carriers who infected their partners.

Although the IgG/IgA ratios varied for each individual patient, they remained relatively constant after treatment for each individual patient.

Low levels of IgM immunoglobulin could be quantitated in 4 of 10 secretions, but binding to gonococci as determined by IFA could not be detected.

Secretions from four uninfected female patients were also studied. A strain of $N$. gonorrhoeae(GC9) known to cross-react broadly in immunofluorescent studies was used as the antigen (12). None of the vaginal secretions had detectable specific IgA antibody, while one patient who was menstruating demon- 
TABLE III

Local Antibodies to N. gonorrhoeae in Male Urethral Secretions

\begin{tabular}{|c|c|c|c|c|c|c|c|}
\hline \multirow[b]{2}{*}{ Patient } & \multicolumn{2}{|c|}{ IFA titer* } & \multicolumn{2}{|c|}{$\begin{array}{l}\text { Immuno- } \\
\text { globulin }\end{array}$} & \multicolumn{2}{|c|}{ Specific titert } & \multirow[b]{2}{*}{$\operatorname{IgG} / \operatorname{IgA}$} \\
\hline & IgG & $\operatorname{IgA}$ & IgG & IgA & IgG & $\operatorname{IgA}$ & \\
\hline & \multicolumn{7}{|c|}{$m g / 100 \mathrm{ml}$} \\
\hline 7051 & 32 & 2 & 14.2 & 4.0 & 2.25 & $(0)$ & 3.6 \\
\hline 7105 & 32 & 4 & 10.2 & 1.3 & 3.14 & 3.08 & 7.9 \\
\hline 7102 & 4 & $<2$ & 1.1 & 0.6 & 3.64 & $(0)$ & 1.8 \\
\hline 7107 & 8 & 8 & 6.2 & 1.8 & 1.29 & 4.44 & 3.4 \\
\hline
\end{tabular}

* Reciprocal titer vs. GC9, indirect immunofluorescence.

\$ IFA titer $\div$ immunoglobulin concentration.

strated specific binding of IgG. The IgG/IgA ratio in these patients was remarkably consistent (Table I).

Secretions from two patients, 134 and 136, were also studied with fluorescein-tagged antihuman colostrum antibody absorbed with normal human serum to render it 11S-specific (Table II). The local IgA response was principally of an 11S nature (secretory IgA antibody).

Urethral secretions from four male patients with acute gonococcal urethritis were studied by immunofluorescence with GC9 as the antigen (Table III). The antibody response was similar to that in the females. Sequential samples could not be obtained since significant urethral discharge ceased with appropriate therapy.

IEA. Vaginal secretions from infected patients could inhibit epithelial cell adhesion of the homologous strain in four out of six instances (Table IV). This activity was relatively specific, i.e. epithelial cell adhesion of the infecting organism was blocked at a higher titer than a heterologous organism. Secretions from uninfected females could not block epithelial cell adhesion of the four strains tested. Both of the patients (135 and 152) who could not inhibit their infecting strain had no IgA detectable by IFA, and patient 135 also lacked specific IgG antibody. No quantitative differences in the ability of gonococci to attach to buccal, cervical, or vaginal cells were demonstrated in three simultaneously determined instances.

Urethral secretions from four males with acute gonococcal urethritis were also capable of inhibiting epithelial cell attachment of their infecting organisms.

Vaginal secretions were collected over a 4-mo period from a single patient (Table V). In this study all of the secretions were standardized to $50 \%$ of an $11 \mathrm{~S} \mathrm{IgA}$ standard (see Methods). The patient had had contact with an infected male 28 days before the initial specimen was obtained and was admitted to the hospital with a disseminated gonococcal infection. Her IEA level remained constant over that period of time, but the relative amount of specific antibody attributable to specific IgA or IgG antibody shifted (Table V).

To determine which antibody class was responsible for the IEA, secretions from Jan. 29, Feb. 9, and Mar. 19 were fractionated in linear sucrose density gradients (Fig. 1). Appropriate fractions were pooled, dialyzed, lyophilized, reconstituted, and tested. Both 11S (IgA) and 7S (IgG) antibodies were responsible for blocking epithelial cell attachment, but the proportion of the antibody class involved shifted over the 4 mo (Table VI). No IgM antibody was detected in the 11S pool.

Although immunofluorescent antibody (IgG) could be measured in only two of five vaginal secretions from uninfected females, all five uninfected patients were capable of inhibiting attachment of strain 418

TABLE IV

IEA by Vaginal Secretions

\begin{tabular}{|c|c|c|c|c|c|c|}
\hline \multirow[b]{2}{*}{ Patient } & \multirow[b]{2}{*}{ Date } & \multicolumn{3}{|c|}{ IEA } & \multicolumn{2}{|c|}{$\begin{array}{l}\text { Specific Ab titers } \\
\text { Immuno- } \\
\text { fluorescence }\end{array}$} \\
\hline & & $\begin{array}{l}\text { Homol- } \\
\text { ogous* }\end{array}$ & \multicolumn{2}{|c|}{ Heterologous $₫$} & $\operatorname{IgG}$ & $\overline{\operatorname{Ig} A}$ \\
\hline \multirow[t]{4}{*}{134} & 9 Jun & 64 & $8,8,8$ & & 0.12 & 0.91 \\
\hline & 17 Jun & 256 & & & 1.84 & 2.35 \\
\hline & 23 Jun & 128 & $8,8,8$ & & 1.88 & 1.54 \\
\hline & 30 Jun & 8 & & & 1.94 & 1.22 \\
\hline \multirow[t]{4}{*}{135} & 9 Jun & $<4$ & & & $(0)$ & (0) \\
\hline & 17 Jun & $<4$ & & & (0) & (0) \\
\hline & 23 Jun & $<4$ & & & (0) & (0) \\
\hline & $7 \mathrm{Jul}$ & $<4$ & & & (0) & (0) \\
\hline \multirow[t]{3}{*}{136} & 17 Jun & 128 & $<4$ & & 0.82 & 5.00 \\
\hline & 22 Jun & 128 & $<4$ & & 2.37 & 0.70 \\
\hline & 30 Jun & 128 & $<4$ & & 36.57 & 0.00 \\
\hline \multirow[t]{3}{*}{143} & $7 \mathrm{Jul}$ & 8 & & & 6.07 & 1.20 \\
\hline & $14 \mathrm{Jul}$ & 8 & & & 3.76 & 4.32 \\
\hline & $21 \mathrm{Jul}$ & $<8$ & & & 2.27 & 0.65 \\
\hline \multirow[t]{3}{*}{152} & 1 Aug & $<4$ & & & 0.80 & $(0)$ \\
\hline & 8 Aug & $<4$ & & & 3.05 & (0) \\
\hline & 21 Aug & $<4$ & & & 0.42 & (0) \\
\hline \multirow[t]{3}{*}{149} & $7 \mathrm{Jul}$ & 8 & & & ND & \\
\hline & $25 \mathrm{Jul}$ & 8 & & & ND & \\
\hline & 8 Aug & 8 & & & ND & \\
\hline N1 & & & $<4 \S$ & $<4<4<4$ & & \\
\hline N2 & & & $<4$ & $<4<4<4$ & & \\
\hline N3 & & & $<4$ & $<4<4<4$ & & \\
\hline N4 & & & $<4$ & $<4<4<4$ & & \\
\hline
\end{tabular}

* IEA vs. infecting strain.

\$ IEA vs. heterologous strain.

$\$$ IEA vs. one of the above infecting strains. 
(Table V) at a low titer. No IgA antibody was detected by immunofluorescence.

To determine whether indirect IFA measured the same antigen(s) involved in attachment of the gonococci to epithelial cells, genital secretions from two patients were absorbed with nonpiliated colony type 3 or type 4 homologous organisms. Although the titers decreased two- to fourfold, IFA and IEA antibody persisted, suggesting that the antigen(s) responsible for attachment (and therefore inhibited) was measured by both assays. Absorption of the same secretions with piliated type 1 or type 2 homologous organisms reduced the IFA and IEA titers to base-line levels.

\section{DISCUSSION}

Kearns et al. (1) and O'Reilly et al. (2), using similar immunofluorescent techniques, demonstrated the presence of local antigonococcal antibody in patients infected with $N$. gonorrhoeae. Their studies concentrated on demonstrating the presence of secretory IgA and quantitating its level over a period ranging from a few days to $9 \mathrm{mo}$. They used a single, broadly cross-reactive strain (GC9) as the antigen (14). In the present study the homologous infecting strain was used as the antigen and the patients were followed for a shorter period of time. Nevertheless, the findings were quite comparable.

TABLE V

Inhibition of Epithelial Cell Attachment of Homologous Strain over 4 mo

\begin{tabular}{cccccc}
\hline & IEA & & \multicolumn{2}{c}{ IFA } & \\
\cline { 2 - 3 } Date & GC418 & IgG* & IgA & IgG & $\begin{array}{c}\text { Specific } \\
\text { IgG }\end{array}$ \\
\hline & & $m g / 100 m l$ & & & \\
29 Jan & $64 \ddagger$ & 5.6 & $16 \ddagger$ & $4 \ddagger$ & 0.71 \\
31 Jan & 64 & & & & \\
6 Feb & 16 & 4.4 & & & \\
8 Feb & 32 & 4.4 & & & \\
19 Feb & 32 & 4.8 & 8 & 32 & 6.67 \\
4 Mar & 64 & 15.0 & 8 & 64 & 4.27 \\
23 Apr & 32 & 10.4 & 8 & 64 & 6.15 \\
19 May & 64 & 5.5 & 4 & 32 & 5.82 \\
Uninfected & & & & & \\
secretions & & & & & \\
N 9 & 2 & $>12.5$ & $<2$ & $<2$ & 0.00 \\
N 12 & 8 & 1.2 & $<2$ & 2 & 1.67 \\
N 14 & 4 & 1.6 & $<2$ & $<2$ & 0.00 \\
N 15 & 4 & 7.4 & $<2$ & 4 & 0.54 \\
N 16 & 2 & 2.2 & $<2$ & $<2$ & 0.00 \\
\hline
\end{tabular}

* Secretions were standardized to $50 \%$ of an $11 \mathrm{~S}$ standard; therefore, IgA titers can be compared directly and need not be standardized (See Methods).

$\$$ Reciprocal of titer

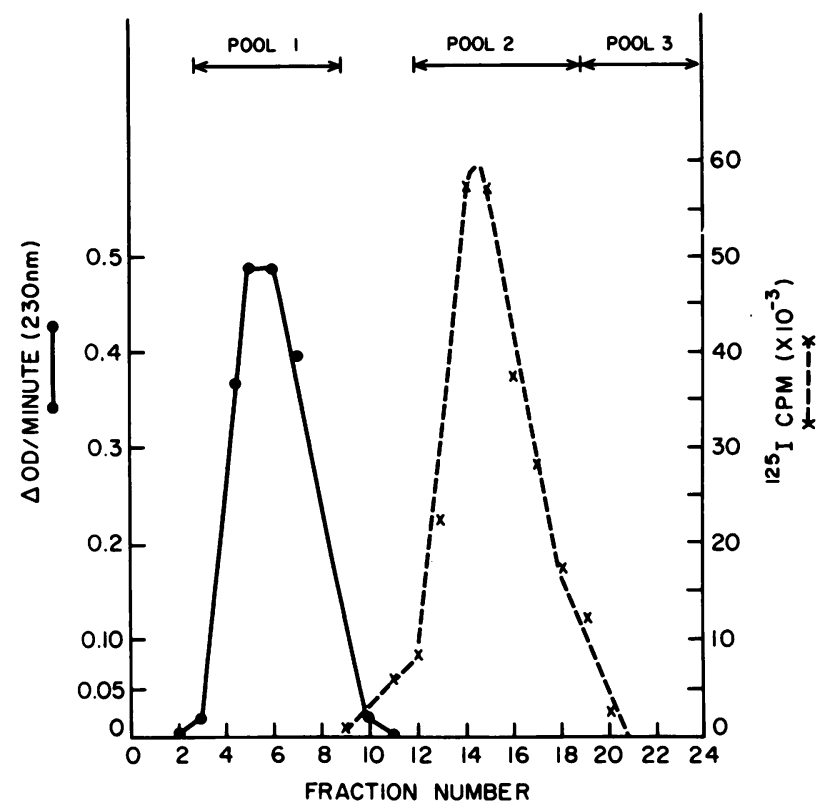

FIGURE 1 Fractionation of vaginal secretions on sucrose density gradient. The 7S marker was purified IgG iodinated with $\mathrm{I}^{125}$; the $11 \mathrm{~S}$ marker was beef crystalline catalase. Markers and secretions were run on different gradients at the same time. Fractions from the secretion gradients corresponding to the marker peaks were pooled and tested.

The present studies confirm the earlier findings that the local IgA antibody response was principally secretory (11S). Of the six female patients O'Reilly et al. (2) studied sequentially, two had a rapid fall in specific IgA antibody titer ( $\leq 10$ days), three had decreased to base-line levels by 50 days, and one patient had persistent high levels for more than 150 days. One of five patients with specific IgA antibody in this study had a rapid decrease to undetectable levels after treatment, while the remaining four patients with specific IgA had persistent but declining levels of IgA antibody at 3-4 wk.

Specific IgG antibody binding to the homologous infecting strains was also demonstrated. These antibodies were present in 10 of 11 patients and persisted throughout the time interval studied. The single patient (135) without specific IgG antibody had detectable IgG by radial-immunodiffusion and IFA when GC9 was used as the antigen, suggesting that she lacked specific IgG directed against strain 135 .

Two patients, both of whom had symptomatic acute pelvic inflammatory disease, had no specific IgA antibody, although patient 135 did have IgA antibody to strain GC9, again suggesting a lack of strainspecific response to GC135. Patient 152 did mount a detectable strain-specific IgG response.

The three patients $(136,148,174)$ who were asymptomatic carriers had the highest initial specific 
TABLE VI

The IEA of IgA and IgG Fractions in Vaginal Secretions

\begin{tabular}{ccccc}
\hline & \multirow{4}{*}{$\begin{array}{c}\text { Unfractionated } \\
\text { secretions* }\end{array}$} & 11S (pool 1) IgA & 7S (pool 2) IgG & Pool 3! \\
\cline { 3 - 5 } & $64 \S$ & 8 & 2 & $<2$ \\
29 Jan & 64 & 4 & 2 & ND \\
9 Feb & 64 & 4 & 16 & ND \\
19 May & 64 & 4 &
\end{tabular}

* Unfractionated vaginal secretions tested the same day.

$\ddagger$ Pool 3 tested as a control.

$\S$ Reciprocal titers.

IgA titers, presumably because of prolonged stimulation by the infecting strains. In each instance the IgA level decreased precipitously while the IgG level remained constant in two and increased in the other. Both patients (134 and 143) named as recent contacts, i.e. cultured as part of epidemiologic follow-up, demonstrated specific IgA titer increases that might represent a response to recent acquisition of gonococci.

The IgG responses did not appear to fall into any pattern that corresponded with the clinical status of the patient as closely as the IgA responses. This may be due to patient variations in the amount of transudation of IgG from serum with or without concomitant local production (preliminary studies revealed IEA activity in serum also). Most of the secretory IgA, on the other hand, is probably made locally $(11,15)$ and may reflect more closely the immunological events taking place on the local surface.

The concentrations of immunoglobulins varied as a result of the dilution of the specimen during collection. Nevertheless, the IgG/IgA ratios were consistent with previous studies that demonstrated a wider scatter of immunoglobulin levels in infected patients (16). Three patients $(134,136,174)$ had their highest concentration of IgG at the time of active infection, which then decreased after treatment. Presumably this is a reflection of the inflammation on the local mucosal surface before treatment. Four patients (135, 143, 148, and 152) maintained relatively constant ratios. However, no consistent clinical presentation existed in these two groups. The ratios reflected relatively lower concentrations of IgA as a result of the 7S IgA standard. For example, Waldman et al. (17) determined specific 11S IgA antibody and reported IgG/11S IgA ratios between $1: 2$ and $1: 4$, which would mean that the secretory IgA concentrations may be as much as 10 times higher than reflected in this study.

How local antibody might protect the host is unclear. Recently, the prevention of attachment by local antibodies of an organism to mucosal cells has been demonstrated. Williams and Gibbons (18) have demonstrated the capacity of secretory IgA to inhibit adherence of cariogenic organisms to human buccal cells.
Steele et al. have also demonstrated the capacity of all three classes of immunoglobulins given orally to protect infant mice from Vibrio cholerae, presumably by inhibiting adherence to intestinal mucosal cells (19). Studies with rabbit antisera have been successful in blocking epithelial attachment of $N$. gonorrhoeae to a number of different cells $(5,20-22)$. The present studies demonstrate that human local secretions have the same ability, and that this capacity appears to be immunologically mediated through both IgG and secretory IgA antibodies. In the single patient studied over a 4-mo period, the IEA titer was maintained between 1:16 and 1:64. At the onset this function was due primarily to $11 \mathrm{~S}$ IgA, but shifted to IgG before the patient was lost to follow-up. Whether this is because she had had a disseminated infection and, therefore, substantial antigenic stimulation resulting in subsequent prolonged transudation of specific IgG into the vagina, or whether the specific IgG was made locally and represents a common sequence of events is not known. Patient 136, an asymptomatic carrier, also demonstrated an apparent similar shift (Tables I and IV). On 30 Jun she had no specific IgA antibody as demonstrated by immunofluorescence, but nevertheless was able to block epithelial cell attachment, presumably mediated by IgG.

All five vaginal secretions from uninfected patients inhibited epithelial cell attachment of strain 418 , although only low titers of IgG could be measured by IFA in only two of them. However, two points must be kept in mind: (a) indirect IFA, which measures antibody that binds to the whole organism dried and fixed onto a slide, and IEA are antibody determinations that most likely detect (share) only a few common antigens, and $(b)$ the relative sensitivity of each test cannot be estimated without knowledge of which specific antigens are involved. However, when the genital secretions were absorbed with nonpiliated organisms that lack those antigens mediating attachment $(6,23-25)$, immunofluorescent antibody persisted. Further absorption with piliated organisms reduced the IFA titer to base-line levels. Thus, it would appear that both antibody tests were measuring the same antigens and that IEA is a more sensitive measurement than IFA of the antibody mediating epithelial cell attachment.

Both patients incapable of blocking epithelial cell adhesion (135 and 152) had symptomatic acute pelvic inflammatory disease. Although the content of immunoglobulin IgG and IgA could be quantitated, neither patient had specific immunofluorescent IgA antibody, while one (135) also lacked specific IgG antibody. One could speculate that $(a)$ neither patient had time to mount a local antibody response because they sought treatment early or $(b)$ they developed an acute symptomatic illness because of an inability to 
block epithelial cell adhesion and, therefore, resist colonization and subsequent tissue invasion. Indeed, all vaginal secretions recovered from asymptomatic patients (carriers) developed IEA antibody.

Virulence of gonococci has been shown to correlate with colonial types 1 and $2(3,26)$. Numerous studies have documented the increased ability of these colonial types to adhere to mammalian cells $(6,23-25)$. With rabbit antisera, inhibition of adherence appears to be relatively specific $(22,27-29)$, and an analogous situation appears to be true for vaginal secretions. In contrast to the homologous strain, patient 134 was able to block three heterologous strains at a low titer that did not change over 12 days (Table IV), while patients 136 (Table IV) and 418 (unpublished observations) were unable to inhibit attachment of heterologous organisms at 1:4 and 1:2 dilutions, respectively. Also, secretions from four uninfected patients were incapable of inhibiting attachment of four different strains (Table IV). In contrast, all five uninfected patients demonstrated some low level blocking activity against strain 418 , suggesting that a significant amount of "natural" antibody directed against this strain existed. It is interesting that patient 418 was unable to infect any of her subsequent male partners (at least two, one of with whom she had at least eight contacts). Also, strain specificity of IEA may help explain the recurrent nature of gonococcal infections.

Recently, gonococci have been shown to elaborate extracellular proteases that can cleave IgA into Fab and Fc fragments (30). However, whether this would alter IEA activity must remain to be seen, since if all that is required for this effect is binding of the Fab fragment to the pertinent antigen (31), then its ability to block attachment may be unimpeded (32).

The nature of gonococcal disease makes it very difficult to be sure with any degree of certainty when the infection actually began. For example, the incubation period as well as the infectivity rate (33) is quite variable, and the patient often has had multiple exposures to one or more partners. Thus, only the dates when specimens were obtained were listed.

\section{ACKNOWLEDGMENTS}

The author wishes to thank CPT Clarence Wilson and SP4 John Bascietto for their technical assistance, Dr. Douglas Tang for help with statistical analysis, Wendell Zollinger for review of the manuscript, and Doris Fisher and Lorraine Taylor for their secretarial help in the preparation of the manuscript.

\section{REFERENCES}

1. Kearns, D. H., R. J. O'Reilly, L. Lee, and B. G. Welch. 1973. Secretory IgA antibodies in the urethral exudate of men with uncomplicated urethritis due to Neisseria gonorrhoeae. J. Infect. Dis. 127: 99-101.

2. O'Reilly, R. J., L. Lee, and B. G. Welch. 1976. Secretory
IgA antibody responses to Neisseria gonorrhoeae in the genital secretions of infected females. J. Infect. Dis. 133: 113-125.

3. Kellogg, D. S., Jr., W. L. Peacock, Jr., W. E. Deacon, L. Brown, and C. I. Pirkle. 1963. Niesseria gonorrhoeae. I. Virulence genetically linked to clonal variation. $J$. Bacteriol. 85: 1274-1279.

4. Swanson, J., S. J. Krause, and E. C. Gotschlich.1971. Studies in gonococcus infection. I. Pili and zones of adhesion: their relation to gonococcal growth patterns. $J$. Exp. Med. 134: 886-906.

5. Punsalang, A. P., Jr., and W. D. Sawyer. 1973. Role of pili in the virulence of Neisseria gonorrhoeae. Infect. Immun. 8: 255-263.

6. Swanson, J. 1973. Studies in gonococcus infection. IV. Pili: Their role in attachment of gonococci to tissue culture cells. J. Exp. Med. 137: 571-589.

7. Avrameas, S., and T. Ternynack. 1971. Peroxidase labelled antibody and Fab conjugates with enhanced intracellular penetration. Immunochemistry. 8: 11751179.

8. Weir, E. M. 1967. Handbook of Experimental Immunology. F. A. Davis Company, Philadelphia. 593.

9. Goldman, M. 1968. Fluorescent Antibody Methods. Academic Press, Inc., New York. 101-104.

10. Mancini, G., A. O. Carbonara, and J F. Heremans. 1965. Immunochemical quantitation of antigens by single radial immunodiffusion. Immunochemistry. 2: 235-254.

11. Tomasi, T. B., Jr., and J. Bienenstock. 1968. Secretory Immunoglobulins. Adv. Immunol. 9: 1-96.

12. Kunkel, H. G. 1960. Macroglobulins and High Molecular Weight Antibodies. In The Plasma Proteins. F. W. Putnam, editor. Academic Press, Inc., New York. 294-307.

13. Reynolds, H. Y., and R. E. Thompson. 1973. Pulmonary host defenses. I. Analysis of protein and lipids in bronchial secretions and antibody responses after vaccination with Pseudomonas aeruginosa. J. Immunol. 111: $358-368$

14. Welch, B. G., and R. J. O'Reilly. 1973. An indirect fluorescent-antibody technique for study of uncomplicated gonorrhea. I. Methodology. J. Infect. Dis. 127: 69-76.

15. Waldman, R. H., and R. Ganguly. 1974. Immunity to infections on secretory surfaces. J. Infect Dis. 130: 419-440.

16. Chipperfield, E. J., and B. A. Evans. 1975. Effect of local infections and oral contraception on immunoglobulin levels in cervical mucus. Infect. Immun. 11: 215-221.

17. Waldman, R. H., J. M. Cruz, and D. S. Rowe. 1972. Immunoglobulin levels and antibody to Candida albicans in human cervicovaginal secretions. Clin. Exp. Immunol. 10: $426-434$.

18. Williams, R. C., and R. J. Gibbons. 1972. Inhibition of bacterial adherence by secretory immunoglobulin A: A mechanism of antigen disposal. Science (Wash. D. C.). 177: 697-699.

19. Steele, E. J., W. Chaicumpa, and D. Rowley. 1974. Isolation and biological properties of three classes of rabbit antibody to Vibrio cholerae.J. Infect. Dis. 130: 93- 103.

20. Koransky, J. R., R. W. Scales, and S. J. Kraus. 1975. Bacterial hemagglutination by Neisseria gonorrhoeae. Infect. Immun. 12: 495-498.

21. Tramont, E. C., J. C. Sadoff, and M. S. Artenstein. 1974. Cross-reactivity of Neisseria gonorrhoeae and Neisseria meningitidis and the nature of antigens involved in the bactericidal reaction. J. Infect. Dis. 130: 240-247.

22. Tramont, E. C. 1976. Specificity of inhibition of epithelial 
cell adhesion of Neisseria gonorrhoeae. Infect. Immun. 14: 593-595.

23. Thongthai, C., and W. D. Sawyer. 1973. Studies on the virulence of Neisseria gonorrhoeae. I. Relation of colonial morphology and resistance to phagocytosis by polymorphonuclear leukocytes. Infect. Immun. 7: 373379.

24. Swanson, J., E. Sparks, B. Zeligs, M. A. Siam, and C. Parrott. 1974. Studies on gonococcus infection. V. Observations on in vitro interactions of gonococci and human neutrophils. Infect. Immun. 10: 633-644.

25. James-Holmquest, A. N., J. Swanson, T. M. Buchanan, R. D. Wende, and R. P. Williams. 1974. Differential attachment by piliated and nonpiliated Neisseria gonorrhoeae to human sperm. Infect. Immun. 9: 897-902.

26. Kellogg, D. S., Jr., I. R. Cohen, L. C. Norins, A. L. Schroeter, and G. Reising. 1968. Neisseria gonorrhoeae. II. Clonal variation and pathogenicity during 35 months in vitro. J. Bacteriol. 96: 596-605.

27. Novotny, P., and W. H. Turner. 1975. Immunological heterogenicity of pili of Neisseria gonorrhoeae. J. Gen. Microbiol. 89: 87-92.
28. Buchanan, T. M. 1975. Antigenic heterogeneity of gonococcal pili. J. Exp. Med. 141: 1470-1475.

29. Buchanan, T. M., and W. A. Pearce. 1976. Pili as a mediator of the attachment of gonococci to human erythrocytes. Infect. Immun. 13: 1483-1489.

30. Plaut, A. G., J. V. Gilbert, M. S. Artenstein, and J. D. Capra. 1975. Neisseria gonorrhoeae and Neisseria meningitidis: extracellular enzyme cleaves human immunoglobulin A. Science (Wash. D. C.). 190: 1103-1105.

31. Smith, T. W., E. Haber, L. Yeatman, and V. P. Butler, Jr. 1976. Reversal of digoxin intoxication with FAB fragments of digoxin-specific antibodies. N. Engl.J. Med. 294: 797-800.

32. Steele, E. J., W. Chaicumpa, and D. Rowley. 1975. Further evidence for cross-linking as a protective factor in experimental cholera: properties of antibody fragments. J. Infect. Dis. 132: 175-180.

33. Holmes, K. K., D. W. Johnson, and H. J. Trostle. 1970. An estimate of the risk of men acquiring gonorrhea by sexual contact with infected females. Am. J. Epidemiol. 91: $170-174$ 